\title{
Questioning Anticorruption in Postcommunist Contexts. Romanian MPs from Commitment to Contestation
}

\begin{abstract}
The outbreak of corruption scandals involving elected officials has raised criticism concerning the quality of parliamentary representation in Romania. The public image of the legislature rapidly became that of a 'reactionary gathering of criminals', persons who use public office in order to cover abuses of power and office. The core contestation of the legislature aimed above all at the usage by parliament of its constitutional privileges and immunities in order to postpone / impede criminal investigations against members of the legislative. Starting from the analysis of the parliamentary speeches of the members of parliament (MPs) under criminal investigation on corruption charges, this paper focuses on the evolving dynamic of acceptance and contestation with respect to the implementation of anticorruption policies. The paper highlights, based on the analysis of the justifications put forward on the occasion of parliamentary hearings, the gradual configuration of a trans-partisan division within the legislature, promoting countervailing, 'anti-anticorruption' discourses, which pit 'anticorruption' and democratic representation against each other.
\end{abstract}

Alexandra Iancu is a Senior Lecturer in the Faculty of Political Science at the University of Bucharest, Romania.

\section{Introduction}

In 2017, hundreds of thousands of Romanians flooded the streets of Bucharest and other major cities in the country to protest at governmental initiatives and justice reforms that appeared conducive to softening the fight against corruption. This degree of mobilization, and especially the contestation of political elites, perceived as corrupt, and more particularly of the party in power initially took the national and international media by surprise. In a country where demonstrations had constituted until recently a relatively marginal phenomenon, such a degree of indignation and mass mobilization around ostensibly technical issues seemed unusual. Nonetheless, to local observers of the political landscape, these social movements were part and parcel of a long line of reactions, with ostensibly different targets but a common denominator in the discourse regarding the inadequacy of the political system in addressing public concerns. Over the past 
years, trust in the elites and the political parties has plateaued at an extremely low level, whereas polls reveal that Romanians do support unelected, executive, and law enforcement institutions such as the army, the anticorruption Prosecutor's Office (National Anticorruption Directorate, Direcția Națională Anticorupție, DNA), and the intelligence services. ${ }^{1}$ Explanations for this phenomenon are complex and relate to various factors such as political culture, the history of the postcommunist transition, the absence of lustration and de-communization, the delays in the reform processes, or-contrariwise-the fluidity of certain reforms. ${ }^{2}$ This shift of perspective in public attitudes has also been caused by agenda setting, namely, the intensification of anticorruption discourses in the trail of the European Union (EU) accession and in lockstep with post-accession policies (i.e. on the transparency and effectiveness of the judicial system and the fight against corruption) monitored by the EU Commission within the framework of the Cooperation and Verification Mechanism (CVM). ${ }^{3}$

Romania is illustrative of the limits and successes of anticorruption reforms within the context of European conditionality. In the early 90s, the processes of hasty privatization of state-owned enterprises fraudulent financial schemes, non-performant credits, and the emergence of new economic entrepreneurs - all

1 The Public Opinion Barometer in Romania (2004-2015) shows that trust in parliament is usually below $20 \%$. In 2016, only $12.8 \%$ of the citizens said they had confidence in the National Assembly (INSCOP, April 2016). On the other hand, at the beginning of 2017 the level of confidence in the Romanian secret services - the Romanian Intelligence Service (SRI) and the Foreign Intelligence Service (SIE) - and in the DNA was around 50\% (Avangarde Survey, Trust in Public Institutions, 6-8 February 2017, in: Bogdan Bolojan, Sondaj proteste Avangarde. Încrederea în institutuții, Dcnews.ro, 11 February 2017, https://www.dcnews. ro/sondaj-proteste-avangarde-increderea-in-institu-iile-statului_532358.html.) All internet references were accessed on 17 June 2018.

2 Mattei Dogan, ed, Political Mistrust and the Discrediting of Politicians, Leiden, Boston, 2005; Pippa Norris, ed, Critical Citizens. Global Support for Democratic Governance, New York, Oxford 1999; Geoffrey Pridham / Attila Ágh, eds, Prospects of Democratic Consolidation, in: East Central Europe, Manchester, New York 2002; Tom Gallagher, Romania and the European Union. How the Weak Vanquished the Strong, Manchester, New York 2009; Iuliana Precupețu, Systemic Factor of Corruption in Romania. Evidence from Discourses on Corruption, in: Angelos Giannakopoulos / Konstadinos Maras / Dirk Tänzler, eds, The Social Construction of Corruption in Europe, Farnham 2012, 195-218.

${ }^{3}$ Ramona Coman, Quo Vadis Judicial Reforms? The Quest for Judicial Independence in Central and Eastern Europe, Europe-Asia Studies 66, no. 6 (2014), 892-924, DOI: 10.1080/09668136.2014.905385; Bogdan Iancu, Separation of Powers and the Rule of Law in Romania. The Crisis in Concepts and Contexts, in: Armin von Bogdandy / Pál Sonnevend, eds, Constitutional Crisis in the European Constitutional Area. Theory, Law and Politics in Hungary and Romania, Oxford, Portland/OR 2015, 153-170; Bogdan Iancu, Standards of 'Good Governance' and Peripheral Constitutionalism. The Case of Post-Accession Romania, in: Giancarlo Corsi / Alberto Febbrajo, eds, Sociology of Constitutions. A Paradoxical Perspective, London, New York 2016, 180-197; Mihaiela Ristei Gugiu, EU Enlargement and Anticorruption. Lessons Learned from Romania, Journal of European Integration 34, no. 5 (2012), 429-446, DOI: 10.1080/07036337.2011.595487. 
these developments often tied to former members of the nomenclature or the secret services - contributed to the perception of endemic corruption. ${ }^{4}$ Starting in the mid-2000s, numerous institutional and legislative reforms undertaken under the European Commission's oversight marked the beginning of a new anticorruption drive. Although the Romanian authorities were reluctant to adopt effective legislative changes and transparency requirements, the implementation of repressive policies (specialized policing and prosecution), bolstered by sustained EU pressure, amounted to significant progress. The best example is the DNA, a structure of the public ministry (formally, the DNA, albeit in reality enjoying complete functional autonomy, is a mere department, or 'directorate', of the General Prosecutor's Office attached to the High Court of Cassation and Justice, Innalta Curte de Casație și Justiție, ICCJ). The institution was created, within the framework of negotiated pre-accession requirements, in 2002 and has jurisdiction over the prosecution of high- and medium-level corruption (defined in terms of either the quality of the defender, the value of the bribe, or the damage to the state). Starting in 2010, the DNA started to build up a record number of pending cases, reaching 11,234 criminal charges in $2017 .{ }^{5}$ The fight against corruption has led to an upheaval of the local political landscape. Traditional parties were compelled to give up or to distance themselves from their leaders, as the latter became mired in various corruption files. Accusations regarding trafficking in influence, abuse of office, giving and receiving bribes, and illicit transactions regarding campaign financing, at both the local and the national levels, made the front pages of newspapers and dominated television breaking news for months on end. Denouncing (the adversaries') corruption and the publicity surrounding high-profile corruption indictments has become commonplace in the local public discourse. Accordingly, the European Commission's reports assessing the progress and providing recommendations on judicial reform and the fight against corruption praised the Anticorruption Directorate highly.

Nevertheless, ten years after, the assessment of the systemic fight against corruption shows mixed results and contradictory accounts. On the one hand the

4 Sebastian Văduva et al., From Corruption to Modernity. The Evolution of Romania's Entrepreneurship Culture, London 2016, 12; Cătălin Augustin Stoica, From Good Communists to Even Better Capitalists? Entrepreneurial Pathways in Post-Socialist Romania, East European Politics and Societies and Cultures 18, no. 2 (2004), 236-277, DOI: 10.1177/0888325403259864.

${ }^{5}$ Since 2010, the anticorruption prosecutors have brought to trial over 1,000 defendants yearly, including over thirty high-ranking officials, in the framework of its high-social-impact cases (Report of 2014). Only in 2015, 1,258 defendants were facing arraignment, including thirty-two dignitaries (a prime-minister, five ministers, sixteen deputies, five senators, etc.). Similarly,, in 2017, thirteen officials were put on trial (three ministers, the chairman of the Chamber of Deputies, one senator, two junior ministers, etc.). In 2017, the conviction rate reached 87.8\%. Direcția Națională Anticorupție (DNA) (National Anticorruption Directorate), Raport privind activitatea desfășurată 2017, http://www.pna.ro/bilant_activitate.xhtml?id=40. 
DNA (with its impressive track record of immutable/final sentences in high-level corruption cases) still stands as a 'proof of efficiency of external conditionality'. ${ }^{6}$ On the other hand, the country continues to rank, in most reports, as one of the most corrupt countries in the region. ${ }^{7}$ Moreover, the spike in DNA activity, in particular bringing charges against high officials, has also subjected this institution to a fair amount of local criticism regarding the selection of cases and the way in which certain cases are prosecuted. From a rhetorical point of view, the struggle or fight against corruption was supported in the pre-accession period by the entire political elite, being perceived as a key indicator of Europeanization. However, various forms of resistance to the dominant anticorruption discourse have gradually crystallized in the media and in political discourses. Among these, one of the most controversial (in terms of public and social perception) is the refusal to lift immunity from prosecution for former and current ministers who are also MPs and the rejection of demands to lift the immunity from pretrial arrest, searches, and seizures of the current deputies and senators. These actions, which are amply criticized both by a segment of the mass-media and by the European Commission, in its CVM progress reports, do not appear to follow either a partisan logic or a coherent pattern. Many of the more recent parliament votes resulting in refusals to yield to the requests made by the DNA seem to validate the positions of the concerned MPs, denouncing or criticizing not necessarily particular abuses by the prosecution or politically motivated charges but rather the premises of anticorruption as such. An 'anti-anticorruption' rhetoric emerged. According to the opponents of anticorruption, the dominant ideology of the anticorruption camp (expressed by politicians supporting it, the EU Commission, local and international NGOs, and the centre-right press) but also the practices used (e.g., by prosecutors, sometimes in collusion with defendants in other cases or in cooperation with the intelligence services) in the fight against corruption are eroding the foundations of representative democracy in Romania.

In the literature on corruption, the backlash potential of the Romanian anticorruption campaign was connected either to the shallow Europeanization thesis or to the nature of the integrity reform. The 'one-size-fits-all' globalized model of the anticorruption strategy (the recipe of accountability, legal innovations, media autonomy, strong civil society, and neoliberal values, ${ }^{8}$ or the inappropriateness of the 'anticorruption arsenal of Western democracies' ${ }^{9}$ showed their limitation in a political system ready to defend the transitional system of acquired and vested privileges. As opposed to this causality-driven

${ }^{6}$ Gugiu, EU Enlargement and Anticorruption, 16.

7 Gugiu, EU Enlargement and Anticorruption, 2; For the presentation of corruption studies and surveys in Romania see Văduva, From Corruption to Modernity, 14-24.

8 Roxana Bratu, Corruption, Informality and Entrepreneurship in Romania, Cham 2018, 83.

9 Văduva, From Corruption to Modernity, 10. 
approach, this paper does not aim at evaluating the nature of anticorruption as such, or the readiness of the local elites to comply with an integrity model of decision-making. Instead, the paper focuses on the concurrent narratives ${ }^{10}$ built around subsequent anticorruption reforms in order to grasp the prevailing political expectations, as revealed by the discursive practices, in terms of transparency and political integrity (as well as their direct connection with the political context at large and their potential impact on the public). ${ }^{11} \mathrm{My}$ argument, within the analytical framework of moderate constructivism, ${ }^{12}$ is that we can trace a pattern of redefining the perception of accepted practices in relation to the evolution of anticorruption policies and the sedimentation of more sophisticated counter-discourses. Consequently, the result of the 'success story' of the Romanian anticorruption policies would not necessarily reside in the long-lasting effects of such policies, or even in the profound change of the political practices of high-level politicians, but in a subtler effect referring to the development of political reflexivity on the scope and nature of democracy and representation.

The study is focused on the intricate relationship between the perception of corruption in recent periods, the anticorruption policies and actors (the denunciators, but also the presumed agents of political corruption), and the discursive strategies adopted within a very fluid political context. Following in the footsteps of de Graaf et al., ${ }^{13}$ the definition of corruption in the public discourse is constructed around perceptions and arguments used by the political actors, bearing on the legitimacy of techniques of influence thought to contradict with the public interest. The political context remains essential for a better comprehension of the deconstruction of public narratives and political polarization, ${ }^{14}$ revealing at the same time the embedded constraints of internal and external political pressures. In what follows, I shall scrutinize the parliamen-

10 Paul M. Heywood, Introduction. Scale and Focus in the Study of Corruption, in: Paul M. Heywood, ed, Handbook of Political Corruption, New York, Abingdon 2015, 1-14, 5.

11 Teun A. van Dijk, What is Political Discourse Analysis?, in: Jan Blommaert / Chris Bulcaen, eds, Political Linguistics, Amsterdam 1997, 11-52, 40.

12 This approach is mainly used in the analysis of corruption from a historical perspective. Michael Johnston, The Search for Definitions. The Vitality of Politics and the Issue of Corruption, International Social Science Journal 48, no. 149 (September 1996), 321-335, DOI: 10.1111/1468-2451.00035; Frédéric Monier / Olivier Dard / Jens Ivo Engels, eds, Patronage et corruption politiques dans l'Europe contemporaine, Paris 2014; Jens Ivo Engels / Frédéric Monier / Natalie Petiteau, eds, La Politique vue d'en bas. Pratiques privées et débats publics dans l'Europe contemporaine, Paris 2012.

13 Gjalt de Graaf / Pieter Wagenaar / Michel Hoenderboom, Constructing Corruption, in: Gjalt de Graaf/Patrick von Maravić / Pieter Wagenaar, eds, The Good Cause. Theoretical Perspectives on Corruption, Opladen 2010, 98-114, 99.

14 Ronald Kroeze, The Rediscovery of Corruption in Western Democracies, in: Jonathan Mendilow / Ilan Peleg, eds, Corruption and Governmental Legitimacy. A Twenty-First Century Perspective, Lanham/MD 2016, 21-41. 
tary debates regarding requests to lift immunity from arrest and prosecution, using the parliamentary records of the Chamber of Deputies and the senate, for 1996, when the first plenary proceedings for the lifting of immunity were held towards the end of the 2012-2016 legislative term. The primary focus of this article is to reveal the structure of justification, beyond the simple arithmetic of vote-tallying in the plenum. The overarching research questions are: what are the distinct narratives competing against each other in the wider framework of the 'success story' of the fight against political corruption, and how have such narratives unfolded and evolved over time?

The analysis contributes to a better understanding of the limitations of intensive and institutionally orientated anticorruption campaigns (and their backfire potential) in new democracies/Europeanization contexts. At the same time, it provides alternative explanations in the quest to comprehend the mechanisms of discursive legitimation of the resistance to anticorruption reforms, or the comprehension of other pathologies - such as the consolidation of populism ${ }^{15}$ or new, aberrant voting behaviours (i.e. voting for those convicted on corruption allegations). ${ }^{16}$

The argument is structured in three parts. The first section of my argument presents an overview of parliamentary immunity, including the main reforms of this institution. The focus of the second bears on the pre-accession period, regarded as paradigmatic for the birth of a dominant anticorruption discourse, unanimously supported by the entire political spectrum. The third enquires into the way in which, after the EU accession, an antithetical narrative emerges, contesting not only discrete anticorruption policies, but also the triumphalist anticorruption discourse as such. In conclusion, I bring into question mainstream interpretations of the relation between immunity, immunity lifting, and corruption per se and reassess the thesis in accordance to which the tabling of integrity on the political agenda would necessarily produce an adjustment in the behaviour of political elites.

\section{Parliamentary Immunity in Postcommunist Romania}

Parliamentary privileges and immunities are often associated with the birth of modern parliamentarism. Initially meant to protect MPs from undue exter-

15 Populist discourses and styles emphasizing the distinction between 'the pure people' and 'the corrupt' elite. Daniele Albertazzi / Duncan McDonnell, Introduction. The Sceptre and the Spectre, in: Daniele Albertazzi / Duncan McDonnell, eds, Twenty-First Century Populism. The Spectre of Western European Democracy, New York 2008, 1-15; Cas Mudde, Populist Radical Right Parties in Europe, Cambridge 2007.

${ }^{16}$ Michael Hein, The Fight against Government Corruption in Romania. Irreversible Results or Sisyphean Challenge?, Europe-Asia Studies 67, no. 5 (2015), 747-776, 748, DOI: 10.1080/ 09668136.2015.1045834. 
nal influences, both stricto sensu, as an implication of parliamentary freedom of speech, and also in the wider sense, encompassing immunity from arrest, search, and seizure (immunity from abusive and harassing prosecution), this institution is nowadays considered an atavism, a throwback from the earlier times of parliamentary emancipation from royal authority. ${ }^{17}$ There are several constitutional traditions in defining parliamentary immunity. The two main paradigms refer to immunity as a form of protection from the abuses of the executive power (the British model), or, following the French tradition, immunity as a form of protection that also involves a degree of autonomy in relation to the judiciary.$^{18}$ Irrespective of the political tradition, the normative conflict between the basic presupposition of the institution (the enlightened, Besitz und Bildung parliament member of classical liberalism) and subsequent evolutions brought about by mass party democracy is at the forefront of political and theoretical debates around immunity. Is an MP above the law? Is immunity a form of discrimination? To what extent should a politician, in a consolidated, mature democracy, receive enhanced protection and guarantees, especially in the case of corruption investigations and charges? The paradox of parliamentary immunity is cogently showcased by Wigley: 'The conundrum posed by parliamentary immunity is that it protects against the possibility of both uncorruptness (the function of representation) and corruptness (the neglect of the function of representation)'. In this particular context, with relatively few exceptions, ${ }^{19}$ most studies of the status of MPs in contemporary democracies, as well as international good practice standards, converge in recommending a reduction of immunities, with a view to enhancing the level of public trust in parliament and combating corruption. ${ }^{20}$

17 In 1629, the Petition of Rights granted English MPs freedom of speech (protection for all laws adopted by the Commons). The British parliamentary tradition, which became widespread in the $18^{\text {th }}$ century, also protected the MPs against arrest and other legal proceedings (depending on the parliament's prior permission). The logic of such an institution was to guard the members of the opposition from abusive arrest (directed by the executive power). The immunity was particularly important in ensuring protection for the MPs in conflict with the king. András Sajó, Limiting Government. An Introduction to Constitutionalism, Budapest 1999, 128-130.

${ }^{18}$ For an analysis of the various facets of parliamentary immunity and traditions: Josh Chafetz, Democracy's Privileged Few. Legislative Privilege and Democratic Norms in the British and American Constitutions, New Haven 2007; Pierre Rosanvallon, Le bon gouvernement, Paris 2015; Simon Wigley, Parliamentary Immunity. Protecting Democracy or Protecting Corruption?, The Journal of Political Philosophy 11, no. 1 (2003), 23-40, DOI: 10.1111/1467-9760.00165.

19 Some authors claim that parliamentary immunity remains a necessity even if the subject of pressure is no longer the executive but other powers in the state. Wigley, Parliamentary Immunity, 23-40; Remco Nehmelman / Max Vetzo, Extension of Parliamentary Immunity, in: Afshin Ellian / Gelijn Molier, eds, Freedom of Speech Under Attack, The Hague 2015, 77-98.

${ }^{20}$ Paul Heywood, Political Corruption. Problems and Perspectives, Political Studies 45, no. 3 (1997), 417-435, DOI: 10.1111/1467-9248.00089; Tilman Hoppe, Public Corruption. Limiting 


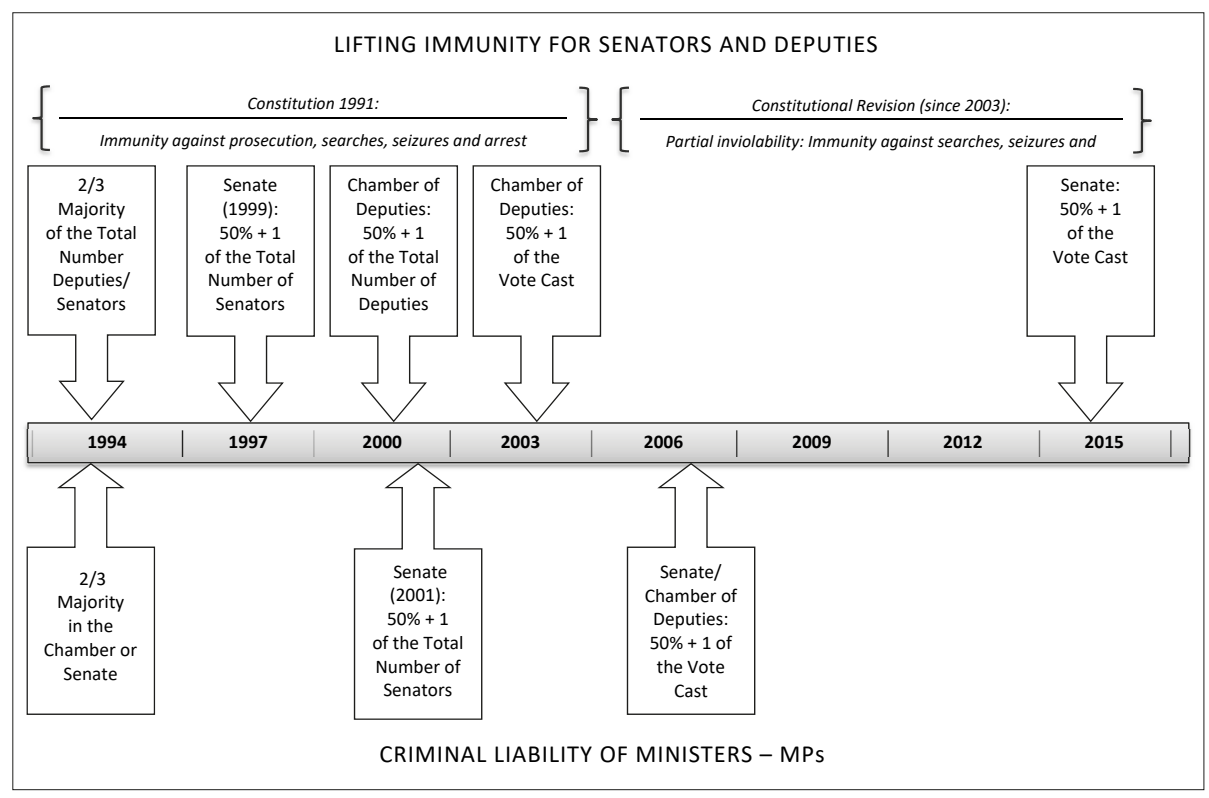

Figure 1. Standing orders majority rules on immunity lifting / prosecution of ministers in Romania-a chronology.

Romanian postcommunist developments appear to fit this general trend, of gradually diminishing immunity. ${ }^{21}$ Both at the level of constitutional and legal norms and at that of public discourse, the necessity for immunity guarantees has been constantly reassessed and brought into question. The local tradition of precommunist, Belgium-orientated constitutionalism (the Constitutions of 1866, 1923) has been followed in this particular respect by the Constituent Assembly of 1991. The drafters opted for extensive protection of the mandate, not only in terms of parliamentary speeches and votes but also in terms of immunity from prosecution, search, and seizure without the prior agreement of the house.

Criminal Immunity of Legislative, Executive and Judicial Officials in Europe, Vienna Journal on International Constitutional Law 5, no. 4 (2011), 538-549, DOI: 10.1515/icl-2011- 0404; Reports on this issue: Sascha Hardt, European Parliament. Parliamentary Immunity in a European Context, Brussels 2015, http://www.europarl.europa.eu/RegData/etudes/IDAN/2015/536461/ IPOL_IDA(2015)536461_EN.pdf; European Commission for Democracy Through Law (Venice Commission), Report on the Scope and Lifting of Parliamentary Immunities, Adopted by the Venice Commission at its $98^{\text {th }}$ plenary session (Venice, 21-22 March 2014), Study no. 714 / (2013), CDL-AD (2014) 011, Strasbourg, 14 May 2014, http://www.venice.coe.int/webforms/documents/default.aspx?pdffile=CDL-AD(2014)011-e.

${ }^{21}$ For the juridical debates Bianca Selejan-Guțan, The Constitution of Romania A Contextual Analysis, Oxford 2016; Ioan Muraru / Elena Simina Tănăsescu, Constituția României. Comentariu pe articole, Bucharest 2008. 
Table 1. Immunity lifts in postcommunist Romania. Total number of cases (votes) and acceptance rates.

\begin{tabular}{|l|c|c|c|c|c|c|c|c|}
\hline & \multicolumn{2}{|c|}{$\begin{array}{c}\text { Criminal } \\
\text { Proceedings }\end{array}$} & \multicolumn{2}{|c|}{$\begin{array}{c}\text { Search and } \\
\text { Restraint }\end{array}$} & \multicolumn{2}{c|}{ Custody } & \multicolumn{2}{c|}{ Total } \\
\cline { 2 - 9 } & Yes & No & Yes & No & Yes & No & Yes & No \\
\hline $1996-2000$ & 3 & 6 & 0 & 0 & 0 & 0 & 3 & 6 \\
\hline $2001-2004$ & 3 & 3 & 0 & 0 & 0 & 0 & 3 & 3 \\
\hline $2005-2008$ & 3 & 5 & 0 & 0 & 0 & 0 & 3 & 5 \\
\hline $2009-2012$ & 2 & 6 & 0 & 1 & 2 & 4 & 4 & 11 \\
\hline $2013-2016$ & 14 & 19 & 3 & 6 & 21 & 30 & 38 & 55 \\
\hline Total & 25 & 39 & 3 & 7 & 23 & 34 & 51 & 80 \\
\hline
\end{tabular}

Source: computed by the author based on stenographic records of parliamentary debates, the Chamber of Deputies, Bucharest.

The degree of protection was initially particularly high, given that a two-thirds majority (of the total number) was necessary to lift immunity from prosecution of a deputy or senator, the same majority needed to adopt constitutional amendments. Beginning in the 2000s, the threshold has been constantly lowered (Figure 1). Although in the first postcommunist decade few requests were made, the status of MPs, in the wake of pre-accession negotiations, underwent significant changes. When the Constitution was amended in 2003, in view of impending EU and NATO accessions, only immunity from pre-trial arrest and search was preserved, so that the two houses of parliament no longer have the power to approve or reject the lifting of immunity from prosecution as such.

In political (but not strictly juridical) debates, the vilification of parliament as a forum for the defence of corruption and corrupt individuals is inextricably related to another form of immunity, namely, that of government members. Members of the government (i.e., ministers), if they are also members of parliament, cannot be prosecuted without the express agreement of their respective house or, if they are not MPs, without the agreement of the president. Initially, the prosecution could ask either institution, irrespective of the capacity of the minister, but following a Constitutional Court decision, the request must be addressed to either the senate, the chamber, or the president, depending on the quality (senator, deputy, not an MP) of the particular minister. Not only was the reach of immunity guarantees diminished in the case of 'simple' MPs (from prosecution to only arrest) but also the majority rule was changed in the case of MPs and minister-MPs, progressively lowering the threshold from qualified (related to the total number) to relative. Unlike the Chamber of Deputies, the senate was more jealous of its prerogatives, maintaining until 2009 a two-thirds majority rule, related to the total number of its members (Figure 1). The temporal discrepancy in what concerns these standing order majority rules appears 
to suggest that, whereas the Chamber of Deputies functioned as a 'shield' for ministers at risk of criminal investigation, the senate operated primarily as a safe haven for its own members.

Irrespective of political strategies, the total number of requests is diminutive (eighty votes in 26 years - see Table 1). Taking into account the relative sizes of the houses, the figures do not appear to support the thesis of an institutional logic relative to actual voting practices. Over the entire postcommunist period, the rate of approval of public-ministry requests to lift the immunity of 'simple' MPs is much higher in the upper house, which was also more reluctant to modify its standing orders in order to relax the threshold needed to approve the lifting of senatorial immunity: $70.8 \%$ in the senate, compared to $60.6 \%$ in the house. Likewise, in the case of deputy-ministers, the institutional inertia in changing the two-thirds-majority rule is for the most part symbolic or, better put, personalized. Before 2009, the house was asked to approve two requests, those concerning the former prime minister Adrian Năstase (request initially denied, subsequently approved in 2009 with over $86 \%$, once the Constitutional Court pronounced on the constitutionality of standing orders amendments to lower the immunity from prosecution threshold to a simple majority) and one minister in his cabinet, Miron Mitrea (request denied). These two cases had first and foremost an important public impact.

From a purely political perspective, the difference between the level of protection enjoyed by cabinet members and simple MPs is unnoticeable in the perception of the public, which regards with suspicion any denial of a request to lift any kind (prosecution, arrest) of immunity. The increased intensity of the fight against corruption brought about a record number of political and public debates on the topic. The higher frequency of cases debated by the plenums of the houses primarily concerned incumbent or former ministers (forty-two out of eighty requests debated). Nonetheless, the results of the votes do not seem to indicate differential treatment by the houses. The approval rates in the case of MPs who are not members of the executive (61.1\%) is similar to that applying to minister-MPs (66.7\%). In fact, despite vigorous media and political criticism, the MPs approve the majority of public-ministry requests to lift prosecution and arrest immunity $-62.5 \%$ (taking into account that the number of requests has also increased). ${ }^{22}$ The relatively small number of individuals concerned by the

${ }^{22}$ There are no clear statistics on the lifting of parliamentary immunity in the European Union. Reports and press articles suggest an important variation in this regard. Greece is an extreme case, with only thirty-one approved requests out of 220 (11-year period, between 2000 and 2011). However, in other European democracies, such as Portugal and Slovenia, the approval rates are quite balanced. In fact, in the French case, which inspired the Romanian constitutional codification of immunity, out of forty-five requests on the lifting of parliamentary immunity, only fifteen were granted. (Immunité parlementaire. Que dit le droit?, Le Figaro, 17 March 2015, http://www.lefigaro.fr/politique/2015/03/17/01002-20150317ARTFIG00102-im- 
procedures (twenty-seven MPs and seventeen minister-MPs, whose cases were extensively debated either in the chamber or in the senate $)^{23}$ is far from validating the public image of parliament as a shelter for the corrupt. It should be remembered here that in the case of ordinary MPs the requests concern parliamentary approvals of detention for 24 hours and pre-trial arrest, which, according to the Constitution, is limited to 180 days. If from a legal point of view minister-MPs benefit from enhanced immunity protections, in practice requests were granted in most cases (twelve out of seventeen). Only in six instances did the senators or deputies not approve any of the requests made by the prosecution.

From a purely political perspective, it is more interesting to inquire into the voting models. An overall analysis of the votes tallied in the course of the past 26 years reveals that none of the traditional or predictable explanations in terms of parliamentary practices explain or predict a refusal or grant of immunity lifting (i.e. being a member of the majority or opposition - thus benefiting from the protection of the peers would facilitate a no-vote, seniority in the party, longer tenure or presence in parliament, political faction affiliation, etc.). Voting variations are particularly significant. Even in more recent times, trans-partisan, contextually coagulated majorities on this issue have been driven by a logic that cuts across the political-party discipline. For example, in the case of votes against immunity lifting, almost half of the MPs protected by their colleagues were members of the opposition (44.8\%). In a similar vein, the political claims according to which the left (particularly the social democrats) is more reactionary in what concerns the anticorruption initiatives finds moderate support in the analysis of voting behaviour. More than 55\% of the proposals to lift immunity of a social democratic MP received approval in parliament. These trends should be read cum grano salis. Recent legislative changes have modified not only the rationale of the voting as such on requests to lift immunity (one cannot waive immunity, save by resigning from parliament) but also the relevance of attendance at the plenum proceedings. The variations in the numbers of senators or deputies taking part in the proceedings often betray implicit opinions. Playing the truant initially functioned as a form of support, so that the quorum or majority could not be reached. Numerous MPs have adopted more recently,

munite-parlementaire-que-dit-le-droit.php); European Parliament. Office for Promotion of Parliamentary Democracy (OPDD), Non-Responsible? Inviolable? Untouchable? The Challenge of Parliamentary Immunities. An Overview, 5 July 2012, https://www.agora-parl.org/ sites/default/files/parliamentary_immunities_final_web.pdf.

${ }^{23}$ The figures provided in the text do not cover all of the ministers-MPs placed under different phases of criminal investigation. In some cases (of non-MP ministers), the president lifted the immunity from prosecution of former cabinet ministers. In several cases, the MPs face criminal prosecution without further requests for search, arrest, or detention. The size of the Romanian Assembly varied from 470 to $588 \mathrm{MPs}$. Moreover, 184 persons were appointed ministers between 2004 and 2014. 
to similar effect, the strategy of ambivalence: they register in order to increase the possibility of reaching the quorum (turnout) requirement without voting (since a negative vote would make them vulnerable to public obloquy or party censure). Out of eighty votes analysed in my paper, in only thirty-three cases did all members present in the plenum cast a vote (for, against, invalid). Given the undifferentiated nature of representations with respect to the kind of protection benefiting political actors (ministers and simple MPs, respectively) and the traditionally unexplainable variance of voting options (which do not reproduce or mirror majority/opposition dichotomies), I undertake in the following to inquire more closely into the rhetoric used in debates on requests to lift immunity from prosecution of government members.

\section{Advocating Anticorruption I. The Meanings of Parliamentary Immunity (1990-2007)}

The discourse concerning the importance of the fight against corruption is an important trope of the Romanian postcommunism. Since the early 1990s, the corruption of the former members of the nomenklatura or the corruption of the members of the governmental leaders came to be an important polarizing factor during the electoral campaigns. Nevertheless, political leaders did little in order to adopt new legislation sanctioning incompatibilities or lack of transparency. ${ }^{24}$ Despite corruption scandals, no major politician was sent to trial on corruption charges. The first signs of reform emerged only after the electoral victory of centre-right 'historic' parties campaigning under the umbrella coalition of the Democratic Convention in 1996. Part of the convention's rhetoric and of its leader and presidential candidate, Emil Constantinescu, targeted 'les nouveaux riches' (in his discourse former members of the communist leadership), ${ }^{25}$ money-laundering practices, fraudulent financial schemes and privatization of former state-owned-enterprises. The creation in 1997, under the coordination of the Romanian presidency, of the National Committee for Prevention of Criminality (CNAICCO) (later replaced by an anticorruption division within the General Prosecutor's Office), the decision of the Supreme Council of National Defense (CSAT) to consider corruption and organized-crime security threats and numerous political proposals for reform raised awareness of the need to reinforce the anticorruption fight and to reform the judiciary. Under the pre-accession negotiation (as the EC reports starting with 1998 noted the problem of corruption in Romania), ${ }_{r}^{26}$ new pressures emerged to adopt an

24 Văduva, From Corruption to Modernity, 11; Precupețu, Systemic Factor of Corruption in Romania, 195-218.

${ }^{25}$ Bratu, Corruption, Informality and Entrepreneurship in Romania, 82.

${ }^{26}$ Gugiu, EU Enlargement and Anticorruption, 7. 
integrated approach. Towards the end of the period, Romania became a member of the Group of States against Corruption (GRECO) and started to adopt new legislation, e.g. law on preventing, detecting, and punishing acts of corruption or the Stability Pact Anticorruption Initiative for Southeastern Europe (2000). ${ }^{27}$ Despite the reformist drive, the new anticorruption discourse did not entail visible outcomes, but produced rather a division within the political system between the 'conservatives' (those sceptical of the political neutrality of such policies) vs the 'reformists', now rebranded as exponents of 'Europeanism'.

Despite vigorous public discussion throughout the second half of the 90s on the need to combat corruption, few immunity-lifting requests were lodged with the parliament. Moreover, in spite of press scandals shedding light on illicit government dealings, media muckraking did not prompt the General Prosecutor's Office to prosecute any government minister. Nonetheless, the fledgling and syncopated debate on the meanings of immunity imposed on the public discourse an interpretive canon, with respect to the meaning of parliamentary immunity, a model which has been taken up in various formulations ever since. What is the meaning of the vote on lifting immunity? What ought to be the framework of reference applied by the MPs when they debate and vote, positively or negatively, on the matter? These are questions that were approached and tentatively formulated for the first time in those years. Regardless of the diversity of cases and scenarios, ranging from accusations of slander, trafficking in influence, providing false information through to intellectual forgery (on a small scale, e.g., staging the theft of one's own automobile with a view to committing insurance fraud) until the first corruption-proper cases, in the 19962000 term (the Gabriel Bivolaru case), ${ }^{28}$ parliament members rapidly reached various definitions of the vote.

Justifications of a favourable vote can be subsumed under a few main tropes, rehashed by the main parties irrespective of their political identities. The main theme is the principle according to which lifting immunity benefits the concerned colleague, insofar as it would allow him or her to 'prove their innocence'. The judicially nonsensical character of this explanation is put in balance with a countervailing discourse on the quest for ethics in politics, according to which MPs whose immunity has been lifted gain an opportunity to defend their names and personal reputations. The rhetoric of the chance to clear one's name is adopted not only by the participants in such debates but sometimes also by the concerned

27 Bratu, Corruption, Informality and Entrepreneurship in Romania, 83.

28 Gabriel Bivolaru (member of the Party of Social Democracy of Romania (Partidul Democrației Sociale din România, PDSR) and MP since 1996) was accused of fraud, forgery, and obtaining illegal credits. The social democrats supported Bivolaru against all allegations until March 1999. Tom Gallagher, Theft of a Nation. Romania Since Communism, London 2005, 220-221. 
MPs arguing that the best proof for the unfounded nature of accusations is the very fact that they want to be brought to justice. ${ }^{29}$ This strand is harmoniously complemented by a second theme, a renvoi to the internal political context. The proof of innocence is thus an element of a wider narrative of re-legitimization of parliament:

'We are the face of an institution that sweeps under the mat deeds that, from the perspective of the common man, are extremely serious, susceptible of being severely punished [...] We find ourselves in an embarrassing situation, I can even predict, without the self-assuredness of others, but I can predict with absolute certainty that the press will again attack, brutally, directly, vigorously, in the best traditions of its trade, the institution of the Romanian parliament, on account of the new evidence for the absurd way in which we function. ${ }^{30}$

At the same time, the MPs of the 90s were concerned about the potential effect of lifting immunity in a mechanical, across-the-board manner, namely, the reduction in the protection of the mandate, and actively searched for interpretive procedures that would discriminate between trivial or vexatious requests and the need to lift immunity in cases of serious accusations. The Bivolaru case, the first grand-corruption request, was debated three times in the plenum, until immunity was eventually lifted (after a third consecutive request by the prosecution); this offered an opportunity to streamline arguments along two discourses. The proposals to identify a methodology on the basis of which requests would be filtered and the necessity of granting immunity lifting would be assessed, taking into account the merits of the prosecutors' case (the solidity of the arguments, or lack thereof, advanced by the prosecution could reveal potential abuses of this instrument) and the overall political context, especially the need to support a functional, effective justice system:

'What we are debating here is the following matter: according to what criteria do we evaluate the lifting of immunity or the denial of the request and that such criteria must be objective, have no relation to party affiliation, ought not to be influenced by press releases and media statements; to such effect we have before us facts, which lead to the formation of personal convictions [...] Therefore [...] if the prosecution, in effect the General Prosecutor's Office, lays before us sufficient

${ }^{29}$ Parliamentary debates concerning the lifting of parliamentary immunity and to allow the prosecution of Nicolae Bud (request rejected), stenographic records, the Chamber of Deputies, Bucharest, 29 May 1997, http://www.cdep.ro/pls/steno/steno.stenograma?ids=1008\&id$\mathrm{m}=5 \& \mathrm{idl}=1$; Parliamentary debates concerning the lifting of parliamentary immunity and to allow prosecution of Viorel Gheorghiu (request approved), stenographic records, the Chamber of Deputies, Bucharest, 1 October 2002, http://www.cdep.ro/pls/steno/steno.stenograma?ids $=5337 \&$ idm $=3 \&$ idl $=1$.

30 The speech of Iosif Boda, MP (PDSR), parliamentary debates on the first request concerning the lifting of parliamentary immunity and to allow prosecution of Gabriel Bivolaru (PDSR) (request rejected), stenographic records, the Chamber of Deputies, Bucharest, 10 June 1997, http://www.cdep.ro/pls/steno/steno.stenograma?ids=1041\&idm=3\&idl=1. 
elements and evidence on the basis of which the groundedness of the prosecution's case is made clear to us, then we must vote affirmatively on the request. If their case is not strong, then we must reject the request. ${ }^{31}$

'Immunity, i.e., our vote for immunity is a vote for Romanian justice system, revealing the degree to which we trust the manner in which Mr. Bivolaru will stand trial. Any argument, either for or against Bivolaru, any juridical argument, has no place here. The matter is whether we trust the judiciary or not $[\ldots] .^{\prime 32}$

The first attempts to reform the judiciary during the 1996-2000 mandate were met with high resistance. The members of the opposition accused CDR's representatives of taking an ideological approach in the reform and of trying to gain control over the judiciary. In this context, the topic of the politicization of justice will consequently become the primary rationale for denying requests to lift immunity from both sides (the members of the majority arguing the lack of profound reforms, while the members of the opposition emphasize the subordination of the judiciary to the new political leaders). The first accusations are brought forth, pointing to the instrumentalization by prosecutors of immunity requests in order to discredit a certain party, 33 the use of 'exemplary' or 'pilot' cases as propaganda tools, in order to capitalize on public image, ${ }^{34}$ and the use of selective prosecution in order to marginalize the opposition. The most radical attacks come from representatives of the right-wing, populist Greater Romania Party (Partidul România Mare, PRM), in debates related to the limits of freedom of speech, but the origins of this discourse can be first found in the Bivolaru case. Gabriel Bivolaru, a social democratic deputy, accused of embezzlement and defrauding a bank of 63 million USD, is the first to invoke in his defence the topic of abusive, selective prosecution:

'[The] request of the Minister of Justice is unchanged, [...] even though the honourable Minister, before the parliamentary faction of the P.D.S.R., in the month of June 1998, stated that "[he] does not seek political revenge". Now, Mr. prosecutor Adam Ion, was rewarded for his merits and promoted to the position of Head of

31 The speech of Emil Teodor Popescu, the Christian-Democratic National Peasants' Party (Partidul Național Țărănesc Creștin Democrat (PNȚCD), parliamentary debates on the first request concerning the lifting of parliamentary immunity and to allow prosecution of Gabriel Bivolaru (PDSR).

32 The speech of Dumitru Sandu, the Social Democratic Party (Partidul Social-Democrat Român, PSDR), parliamentary debates on the second request concerning the lifting of parliamentary immunity and to allow prosecution of Gabriel Bivolaru (PDSR), stenographic records, the Chamber of Deputies, Bucharest, 25 February 1999, http://www.cdep.ro/pls/steno/steno. stenograma?ids $=2842 \& i d m=3 \& i d l=1$

33 Parliamentary debates concerning the lifting of parliamentary immunity and to allow prosecution of Cornel Sturza-Popovici, stenographic records, the Chamber of Deputies, Bucharest, 8 February 1996, http://www.cdep.ro/pls/steno/steno.stenograma?ids=83\&idm=5\&idl=1

34 The speech of Crin Antonescu, the National Liberal Party (Partidul Național Liberal, PNL), parliamentary debates concerning the lifting of parliamentary immunity and to allow prosecution of Viorel Gheorghiu. 
the Anticorruption Division, Prosecution and Criminalistics within the General Prosecutor's Office attached to the Supreme Court of Justice. [Mr. Ion was] a part of the team around Minister Stoica, which has made "Revolution in the Public Ministry and the Justice System", the minister forgetting however or not knowing the fact that I made against this prosecutor, Adam Ion, numerous complaints about forgeries committed by the latter, forgeries proven with documents appended to the file, and which have remained miraculously unaddressed up to now. I remain at the same time unconvinced that the statement of the minister, regarding his mistrust in the very department he is leading, accompanied by a letter of protest by the Magistrate Association, with respect to certain nefarious influences on the justice system, and also the recent resigning of a magistrate, who accused undue influence and pressures, will constitute genuine topics of reflection and debate, bearing on the manner in which you will exercise your prerogative to vote on this request concerning my immunity.' 35

The contestation of judiciary actions - the alleged politicization of magistrates, rewards for prosecutors instrumenting accusations against the political foes of the party in power, the replacement of case prosecutors (accusations often made in such cases, sometimes even by members of the governing parties or coalitions), ${ }^{36}$ will be amplified in direct proportion to the increase in the number of requests to lift immunity made to parliament. As it happened, the redefining of the procedural logic of voting on such demands, at least on the declaratory level, divides the positions made also between those discussing files on the merits and those formulating general prudential arguments, revolving on the issue of opportunity and context. In this latter respect, the internal context is not the only variable. The reputational argument (preserving/acquiring a good international standing, particularly by adopting 'European' - that is, 'EU' - good practices and benchmarks), constitutes an important rationale in discourses endorsing integrity campaigns in contemporary Romania. The first rhetorical references to international pressures - as constraints on political behaviourarose first in relation to 9/11, during the debates on two requests made by the prosecution to lift the immunity of two MPs of the radical right-wing party, PRM. These were accused of providing false information in press conferences (the two MPs had declared against the backdrop of the terrorist attacks that the Romanian state had sheltered and trained members of terrorist organizations). In Parliament, the proponents of voting affirmatively to lift the immunity of

35 Parliamentary debates on the first request concerning the lifting of parliamentary immunity and to allow prosecution of Gabriel Bivolaru (PDSR); Parliamentary debates on the second request concerning the lifting of parliamentary immunity and to allow prosecution of Gabriel Bivolaru (PDSR).

36 The speech of George Iulian Stancov (Partidul Democrat, PD), parliamentary debates on the second request concerning the lifting of parliamentary immunity and to allow prosecution of Gabriel Bivolaru (PDSR). 
these two parliamentarians emphasized the moment, as particularly detrimental to the country's international reputation. The timing of the statements and the damage caused by the culprits to the country's international reputation in this particularly sensitive context became an aggravating factor, almost unanimously condemned in the plenary session.

\section{Advocating Anticorruption II. Post-Accession. From Acquiescence to Rebellion}

The beginning of the 2000s brought important institutional changes, against the backdrop of the pre-accession negotiations. The social democratic cabinet adopted the first anticorruption strategy (in 2001), ratified rapidly the international framework (the CoE criminal and civil conventions against corruption), and passed legislation on public procurement, public finances, money laundering and public finances, transparency, declarations of interests, etc. The government also created in 2002 the PNA (National Anticorruption Prosecutor's Office, the precursor of the DNA (2005)) through an emergency ordinance. The institution was intended to meet EU expectations in terms of fighting grand corruption, and benefited from a grant support of $€ 2$ million from the 'Poland and Hungary Assistance for Restructuring of the Economy' (PHARE) programme. ${ }^{37}$ The prosecutors, already empowered by the constitutional revision of $2003^{38}$ also received a special status and much higher wages than their peers in the general structure of the public ministry (increases of $40 \%-75 \%$ ). ${ }^{39}$ The electoral victory of the centre-right political alliance DA in the 2004 and the presidential victory of Traian Basescu in 2004 on an anticorruption platform boosted both the reformist drive and the political polarization on anticorruption issues. New institutions were rapidly built up (the Fight Against Fraud Department, Departamentul pentru luptă antifraudă, DLAF; the Anticorruption General Directorate, Direcția Generală Anticorupție, DGA; the National Integrity Agency, Agenția Națională pentru Integritate, ANI), and laws on campaign finance and public administration were adopted.

The great contentions around corruption indictments appear in the postaccession period, after 2007, against the backdrop of the Mechanism of Cooperation and Verification for Romania and Bulgaria. A new 'season for corruption

37 Gugiu, EU Enlargement and Anticorruption, 13.

38 The constitutional revision in 2003 strengthened the role of the Superior Council of Magistracy (CSM) and diminished the attributions of the minister of justice. For further details on the CSM reform and its impact on Prosecutorial office empowerment, notably on the DNA, see Iancu, Standards of 'Good Governance' and Peripheral Constitutionalism, 180-197.

39 Bratu, Corruption, Informality and Entrepreneurship in Romania, 88. 
fighters' came to life targeting high-level politicians. ${ }^{40}$ Cases of public notoriety, implicating prime ministers, acting ministers, and senior parliament members have prompted numerous realignments in relation to the meaning and role of anticorruption and in particular with regard to the activity of the DNA. It is unquestionable that the exponential increase in high-corruption cases has also provided fodder to the 'defence' repertoire. From appeals to God or appeals to mercy (invoking family situations and poor health) to the overt admittance of personal incompetence, the stenographic records of the debates bear witness to an abundant, rich imaginary of those accused of corruption crimes. Although the parliamentary default position of diffidence or defensiveness, albeit often declaratory, remains, one can notice a fault-line between (on the one hand) positions voiced in the plenary sessions and the statements of the faction whips and (on the other) the actual results of the votes. Furthermore, substantive, reflexive debates are on a downward spiral. If, for example, the stenographic record of a debate on immunity lifting in 2008 spans over 100 pages, it currently ranges around less than ten pages in length. Even though the concerned members, in their positions, continue to underline on the files as such and various misgivings related to the prosecution requests (absence of evidence, files built on truncated wiretap transcripts, files built solely on the testimony of informants), the focus of the debate shifts towards two additional dimensions. The opposing camps are highly polarized. On one side, MPs supporting anticorruption as paramount state policy endorse the principle of lifting immunity: according to this camp, MPs should approve all prosecutorial requests automatically, without further debate. Other MPs stress the importance of parliamentary procedure, democratic/political choice, insisting on deliberations on a case-by-case basis, so that each request from the DNA should be dealt with on its own merits. This latter camp refers to the politicization of the anticorruption Prosecutor's Office and the detrimental effects of its actions on the Romanian democracy writ large.

The first opportunity to reopen the issue appeared one year after the accession. MPs revisited the arguments of the 90s/early 2000s, underlying at the same time the need for a positive response to the requests for lifting immunity, an affirmative answer being considered in tune with the 'European commitment' of the country. The image of Romania on the international scene, the acts of justice are rapidly brought in line with the need or ideal of forging a political landscape above blemish or suspicion:

'Nowadays, in the current situation, to reject such requests does nothing but hurt the country, in its position within the EU, the parliament, as an institution, us, as its members, as representatives of the nation. It damages also those who are under investigation, since they will remain under suspicion of guilt $[\ldots]$ my dear colleagues, please consider that no one has anything to gain if under the veil of

${ }^{40}$ Hein, The Fight Against Government Corruption in Romania, 747. 
voting secrecy, in the current context, when day by day we understand better the sheer magnitude of the phenomenon of corruption in Romania, it does no good to anyone to reject the demands of the justice system. ${ }^{41}$

In this setting, the need to ignore the file forwarded by the prosecutors is clearly stated, not just by individual MPs but by the report of the Senate Judiciary Committee in a case in which, despite a wave of criticism regarding the file from all factions, the senate would unanimously vote to agree to the prosecution of the respective minister:

'The Judiciary, Discipline, Immunities and Validation stresses that, should the request be rejected, the official would be deprived of the possibility to demonstrate his innocence by administering evidence on his behalf and by subjecting himself to a fair and equitable trial [...] Otherwise, he would continue to remain under suspicion of having committed a serious offence, suspicion that is inimical to the respect due to the rule of law [...]. The file sent to us by the General Prosecutor's Office attached to the High Court of Cassation is in our opinion confused and inconclusive, a series of elements being included in it irrelevant to the accusation's case, which leads us to conclude that either other evidence exist which justifies such an approach, but has not been submitted to the Senate, or that the position of the prosecution rests in good measure on unfounded presuppositions, allegations, speculation, and suspicions of guilt [emphasis mine]. ${ }^{42}$

On the occasion of this highly publicized debate, with the expectation of those directly concerned, challenges to the prosecution's case have been marginal and did not have any impact on the vote as such. The only substantive criticism came from the PRM, claiming selective prosecution and requisition a stay of criminal proceedings, amid more general allegations regarding the 'servile' attitude of the national political actors, kowtowing before the CVM conditionality. But, paradoxically, even this party called for a lifting of ministerial immunity from prosecution.

Beginning in 2014, against the background of an increase in the number of high-profile cases debated in parliament, criticism targeted also the functioning of the Prosecutor's Office. For the most part, the parties sum up their respective positions either in a general statement on the voting intentions or dwell on minute procedural aspects. Nevertheless, new types of critical arguments begin to crystallize, announcing general attitudes of disapproval relating to the direction or configuration of anticorruption policies. The criticism of the quasi-

41 The speech of Ludovic Orban (PNL), parliamentary debates concerning the lifting of parliamentary immunity and to allow arrest and detention of Theodor-Cătălin Nicolescu, stenographic records, the Chamber of Deputies, Bucharest, 25 March 2015, http://www.cdep. $\mathrm{ro} / \mathrm{pls} /$ steno/steno.stenograma?ids=7476\&idm=23\&idl $=1$.

42 Judiciary Committee Report read by Norica Nicolai (PNL) at the special session on the immunity lifting of Codruț Șereș (minister-MP), stenographic records, the Senate of Romania, Bucharest, 26 August 2008, https://senat.ro/PAGINI/Stenograme/Stenograme2008/08.08.26. PDF. 
automatic lift of immunity (namely the assumption that immunity ought to be automatically lifted in all cases as a demonstration of support for the rule of law) proceeds from a series of procedural claims. Three main ideas underpin it. First, the trans-partisan notion that the competence of the houses to decide on requests implies a responsibility for the votes individually cast and therefore a responsibility for thoroughly studying the file/case under review before voting on the request. Second, MPs differentiate between the prosecutors, and especially the DNA (often criticized in the debates), on the one hand, and justice proper, i.e., the courts of law. Third, in the Euro-sceptical, sovereignty-centred key, some parliament members refer to the representative logic of their mandate and the need to vote according to one's conscience rather than through the proxy of party politics or external pressures (coming from other internal institutions, such as the Superior Council of the Magistracy, or external structures, such as the Commission within the framework of the CVM).

'Whether the act of justice is or not conditional on parliament approval cannot divest us from the responsibility of the vote $[. .$.$] otherwise we shall have become a sort$ of one-stop shop which receives and rubber-stamps documents [...]. The mere fact that the competence of MPs to make proposals is under debate, the fact that our obligation to render a certain decision is questioned, the fact that the separation of powers has come to be understood as our not having a right to voice our concerns but the privilege to be trampled underfoot or the privilege of others to tread on us, all of this seriously undermines the possibility of democracy and the rule of law in Romania. I shall not dwell on the matter that this is not a request of the judiciary [...] proper justice is accomplished in Romania in the High Court of Cassation and Justice and the other courts instituted and established by the law. We have received no such request from a court of law. We have before us a request made by the Public Ministry, the General Prosecutor's Office by the High Court of Cassation and Justice and we shall regard it with the utmost consideration [...]. Even in the last [CVM, EU Commission] report mention is made of the fact the parliament lacks in political will, a statement that is absolutely unacceptable, be it only in view of the fact that the Constitution defines the parliament as supreme representative body of the Romanian people [...] we cannot have so-called objective criteria underlying our vote and we need not justify our votes vis-à-vis EU Commission experts or anyone else, having to account solely to our electorate, which charged us with this mandate [and its responsibilities]. ${ }^{43}$

Such arguments visibly serve instrumental purposes, notably providing a public justification for selective endorsements in voting for immunity lifting, providing

43 The speech of Şerban Nicolae (PSD), stenographic records, sessions of the Senate of Romania, parliamentary debate concerning the vote to lift immunity from prosecution, detention and preventive arrest of Darius Vâlcov, Bucharest, 1 April 2015, https://senat.ro/PAGINI/ Stenograme/Stenograme2015/15.04.01.pdf; of Dan Șova, Bucharest, 3 December 2015, https:// senat.ro/PAGINI/Stenograme/Stenograme2015/15.12.03.pdf; of Gabriel Oprea, Bucharest, 3 February 2016, https://senat.ro/PAGINI/Stenograme/Stenograme2016/16.02.03.pdf. 
a framework of defence for those put in question by the prosecutorial office. Nevertheless, the merit of the debate resides in raising awareness in the logics of institutional functioning and the meaning and scope of political representation under the Romanian constitutional provisions. This process of reflection of the constitutional foundations and the internal political logics of state powers was overlooked or marginalized in the debates on the constitutional drafting and revision in 1991, respectively in 2003. The simple effort to find institutional and technical justifications for political decisions, even in such extreme cases, marks a new phase in the articulation of political narratives at various times by the political actors from the right as well as from the left-side of the aisle. New types of denunciations, referring to due process (and individual rights and freedoms at large), are also eroding the position according to which the indictment (in the case of acting ministers), but primarily the pre-trial arrest (in the case of both simple MPs and minister-MPs), would be a chance or opportunity to prove one's innocence. The large number of instances in which requests to lift immunity were made recently has rendered the MPs more cautions, especially as many such requests concern actions committed a long while back and arguably could have been prosecuted sooner, or which have been pending for a long time.

'I know that many say I should go to the Prosecutor's Office to help a quest for truth. I must tell you, esteemed colleagues that going to the prosecutors is not some sort of symposium to debate on truth. The person under investigation is effectively ousted from public life. His destiny and the fate of his family are subjected to rigours, which are implicit in the functioning of criminal justice. In the best-case scenario, if one is acquitted, this will have happened after many years, without the possibility to ask for any sort of just satisfaction from the state, whereas the responsibility of magistrates is not regulated. ${ }^{\prime 4}$

Criticism of this practice (i.e., pre-trial arrest) has in effect reached a high-water mark in recent years. Many MPs imply that behind such requests is not some abstract pursuit of justice but the intent of the prosecutors to bring pressure to bear on those arrested, in order to turn them into informants. In this general context, most MPs share the idea that officials ought to be prosecuted while free and vote accordingly. This newer trend opposes the imperative of anticorruption with the imperative of rights and liberties; needless to say, the discourse also lends itself easily to self-interested pleas. One MP who benefited from a rejection of the request of the prosecution to approve lifting immunity from arrest and used this break in order to flee from prosecution to Serbia made the following statement when the request was debated in the chamber:

${ }^{44}$ The speech of Varujan Vosganian (PNL), parliamentary debate concerning the procedure of lifting immunity from prosecution in the case of Varujan Vosganian, stenographic records, the Senate of Romania, Bucharest, 12 February 2015, https://senat.ro/PAGINI/Stenograme/ Stenograme2015/15.02.12.pdf. 
'Please show that the parliament of Romania rejects the use of arrest as pressure instrument, which puts democracy under strain. The notion that an MP is above the law is mere falsehood. The vote of today, as in other cases, shall not throw a spanner in the works of the judicial system but only signify a firm response to an abusive practice: arrest before trial. The parliament of Romania is under immense pressure, and all means, juridical institutions as well as the media, are wielded to influence it. But to what purpose? The purpose is that which you whisper on the hallways, you whisper to your friends: a regime of fear spawned by repression and the use of arrest as a modern instrument of torture, in order to squeeze out information and informants. The preventive, pre-trial arrest of someone for a deed, which happened many years ago has the purpose of annihilating his social status, of breaking his family ties, of creating a presumption of guilt before the trial has even started. ${ }^{\prime 45}$

A major shift in terms of the parliamentary perception of such requests concerns the claim that the repressive penal policies enforced by the DNA is necessarily compatible with the principles of representative democracy. Although the DNA's effectiveness has been appreciated in EC country reports and in the international public discourse, the legitimacy of the institution has more recently been increasingly questioned in internal political and public debates. In the framework of this argumentative cluster, MPs inquire into the general problematics of separation of powers and denounce systematic intrusions of the prosecutors in politics (criminalizing the electoral process as such, prosecuting selectively in order to influence the political competition). Such positions are ever more often addressed from the lectern of parliament by key politicians. Victor Ponta, the prime minister in office at the time, criticized the prosecution's request (an approval of the demand for lifting his immunity from prosecution would have implied automatic suspension from office) in the following terms:

'You have to decide whether another state power or a representative thereof, the case prosecutor, may oversee, may prosecute those who adopt general political decisions. I believe it is an extremely important matter that you have to apply yourselves to today and I trust this ought to constitute a precedent for the way in which checks and balances will operate in the future. The second issue, equally important to a democratic system is the following: a government that of Romania or any other democratic country, is vested and revoked through parliamentary procedures. The constitutional procedure is clear and means a vote of confidence after the elections and-respectively-a motion of censure, a vote of no confidence. I have become prime minister and must thank my colleagues in the Social-Liberal Union [USL, a coalition of social democrats and national liberals], which adopted a motion of censure that brought down the Ungureanu government, a motion of censure therefore not a criminal indictment against Mihai-Răzvan Ungureanu [...].

45 The speech of Sebastian Ghiță (PSD), parliamentary debate concerning the vote to lift immunity from prosecution, detention and preventive arrest of Sebastian Ghiță, stenographic records, the Chamber of Deputies, Bucharest, 30 March 2016, http://www.cdep.ro/pls/steno/ steno.stenograma?ids $=7647 \& i d m=6 \& i d l=1$. 
It is my conviction that you must decide now if we shall preserve this [democratic] mechanism in the future, so that governments shall be elected and revoked by the parliament or if governments are to lose their mandate through acts of the representatives of other state institutions. ${ }^{\prime 46}$

Disapproval of precise prosecutorial actions has increased significantly in intensity, also as a direct consequence of the escalation of media focus on the judiciary (accusations of abuse, targeting institutions and certain prosecutors in the DNA, press campaigns about the cases of prosecutors sanctioned disciplinarily by the CSM, etc.). Criticism in the media heightened the legitimacy of the anti-anticorruption discourse, a newer narrative that at times embraces conspiracy-theory overtones, building on media debates on the operative cooperation between the internal intelligence service and the DNA (until 2016, when the Constitutional Court rendered this practice unconstitutional and thus illegal, the Romanian Intelligence Service (Serviciul Român de Informații, SRI) executed the wiretap warrants in anticorruption cases $)^{47}$ :

'This is a well-organized, concerted action, [...] aiming at aggrandizing power, by the system composed of representatives of the intelligence community, the enforcement institutions (instituţiile de forţă) and the judiciary. This smokescreen, this veil that is becoming increasingly transparent, obfuscating the system is represented by anticorruption, an undertaking brilliantly chosen due to the fact that [the principle as such] enjoys popular support. In a country in which corruption has permeated all social structures, and where public perception levels on the phenomenon of

46 The speech of Victor Ponta (PSD), parliamentary debate concerning the procedure of lifting immunity from prosecution in the case of Victor Ponta, the prime minister of Romania, stenographic records, the Chamber of Deputies, Bucharest, 9 June 2015, http://www.cdep.ro/ pls/steno/steno.data?cam=2\&dat=20150609\&idl=1.

47 Public allegations regarding the intricate relationship between the Romanian Intelligence Service (Serviciul Român de Informații, SRI) and DNA continue to date. In January 2017, the press wrote about the so-called 'joint teams of prosecutors and DNA representatives' that functioned on the basis of secret inter-institutional agreements. The two institutions denied the information. However, the controversies on the connection between the DNA and SRI continue, as in a previous interview, in 2013, the DNA's chief Prosecutor acknowledged the existence of such agreements and declared that the institution received much information from the Romanian Intelligence Service (Simona Ionescu / Ionel Stoica, The interview with Laura Codruța Kovesi, the DNA's chief Prosecutor, Evenimentul Zilei, 13 December 2013, http://evz. ro/interviurile-2-1-laura-codruta-kovesi-1072253.html). The current controversies carry on with previous debates. In 2016, a series of press articles denounced the close connection between the SRI and DNA in connection to the fact that the SRI had been executing technical-surveillance mandates ordered by Court in cases of criminal investigations. The Constitutional Courts' decision no. 51/2016, on the admissibility of the objection of unconstitutionality in the case of Article 142 (1) of the Criminal Code disrupted this modus operandi. The decision rendered by the Court regarded the fact that only the criminal prosecution bodies or the police (and not by 'other state bodies') had the authority of conducting technical surveillance (e. g. interception of communications, access to a computer, photo-video surveillance, financial transaction data, etc.). According to Kovesi's own estimates, almost half of the completed files in 2015 relied on technical surveillance. 
corruption are high, any anticorruption endeavour is naturally supported, even if it would lead to the suppression of democracy itself. Too many times have I heard the assertion that law can be bent, if only this would lead to the arrest of certain politicians [...]. If we were to look into the lives of those representing this discourse, we should find out that they are no better, bear the marks of the same sins, may be at any point accused of the same misdeeds, the distinction residing only in their lack of legitimacy, given that no one elected them, but rather they were politically promoted to the positions they now fill.' 48

The recent political focus of contestation of DNA exploits the 'foreign' origin of the institution, created under EU pressure. The transformation of the anticorruption prosecutors in 'elite squads' endowed with symbolic and financial resources, the recruitment of the personnel among young prosecutors, the 'internationalization' (including preferential contacts with EU officials, international press, foreign embassies) coupled ${ }^{49}$ with high institutional autonomy makes the institution a visible and easy target. More and more politicians are exploiting flaws or deficiencies in the functioning of the institution as means of self-legitimation. This political discourse is also echoed by new social agents. In the mid-2000s, the intensive European financial support for the anticorruption industry and moral entrepreneurs consolidated this segment of the Romanian civil society. ${ }^{50}$ The initiative also allowed the polarization of the social sphere. Media outlets and challengers of mainstream position, the outsiders of the anticorruption industry, came to light exploiting the lack of a counter-discourse on modernization and democratization.

\section{Conclusions}

The debates on lifting immunity from prosecution or arrest of ministers concerned primarily political corruption cases. The number of indictments and judgements has increased gradually, and so did media attention to the general topic. Interesting in this context is less the logic as such of the vote on the requests of the public ministry but the absence of politically driven logic that one encounters in the sense of party politics. The CVM reports of the Commission underline precisely the explanatory vacuum of votes rejecting requests made by the prosecution. MPs reply by invoking freedom of conscience, the representative mandate, basic principles of the democratic vote, principles that are all the more salient in cases where ideological positions and affiliations (e.g.,

48 The speech of Elena Udrea, Former leader of the Democratic Liberal Party (Partidului Democrat Liberal, PDL), minister/Independent, parliamentary debate concerning the procedure of lifting immunity from prosecution stenographic records, the Chamber of Deputies, Bucharest, 28 October 2015, http://www.cdep.ro/pls/steno/steno.data?cam=2\&dat=20151028\&idl=1.

49 Bratu, Corruption, Informality and Entrepreneurship in Romania, 226.

50 Bratu, Corruption, Informality and Entrepreneurship in Romania, 8. 
implementing the party platform) are not relevant. While the discussion on the meaning of parliamentary representation and on the scope of the decisionmaking prerogatives constitutes an important qualitative step towards the sophistication of the political discourse, the debates remain strongly polarized and they do not necessarily reflect in broader appeals or political initiatives concerning policy-related reforms (such interrogations are solely concerned with anticorruption or reform of the judiciary).

Debates on political corruption are widespread. Abuse of power and attacks on it are on the agenda, to various degrees, in other European democracies as well. In other states, for example Italy, anticorruption campaigns were also short-lived and did not effect long-term structural changes for the better. ${ }^{51}$ Political scandals as such recurrently surface in states such as Spain, Portugal, and newer democracies confronted with a strong erosion of political representation. ${ }^{52}$ In most cases, the deficient legislative framework or local resistance (political culture, political strategic behaviour) are cited as classical sources of 'reactionary' behaviour. If differences exist at the European level in terms of the micro-techniques of power, particularly the colonizing of public goods, ${ }^{53}$ in all these cases one may notice that the accusations of corruption are not automatically reducing the chances of being elected or selected in governmental structures (candidates suspected, indicted, or even convicted of corruption crimes routinely get (re)elected). ${ }^{54}$ The Romanian case does not appear to deviate from these patterns. Legislative deficiencies, political inertia, and lack of correlation between poll results showing support for anticorruption and the vote results as

51 Donatella Della Porta / Alberto Vannucci, Corruption and Anti-Corruption. The Political Defeat of 'Clean Hands' in Italy, West European Politics 30, no. 4 (2007), 830-853, DOI: 10.1080/01402380701500322; Salvatore Sberna / Alberto Vannucci, 'It's the Politics, Stupid!' The Politicization of Anti-Corruption in Italy, Crime, Law and Social Change 60, no. 5 (2013), 565-593, DOI: 10.1007/s10611-013-9480-8.

52 Fernando Jiménez, Building Boom and Political Corruption in Spain, South European Society and Politics 4, no. 3 (2009), 255-272, DOI: 10.1080/13608740903356541; Miklós Bánkuti / Gábor Halmai / Kim Lane Scheppele, Hungary's Illiberal Turn. Disabling the Constitution, Journal of Democracy 23, no. 3 (2012), 138-146, DOI: 10.1353/jod.2012.0054; Kim Lane Scheppele, The Rule of Law and the Frankenstate. Why Governance Checklists Do Not Work, Governance 26, no. 4 (2013), 559-562, DOI: 10.1111/gove.12049; Agnes Batory, Why Do Anti-Corruption Laws Fail in Central Eastern Europe? A Target Compliance Perspective, Regulation and Governance 6, no. 1 (2012), 66-82, DOI: 10.1111/j.1748-5991.2011.01125.x.

53 Ingrid van Biezen, Political Parties as Public Utilities, Party Politics 10, no. 6 (2004), 701722, DOI: 10.1177/1354068804046914; Ingrid van Biezen / Peter Kopecký, The State and the Parties. Public Funding, Public Regulation and Rent-Seeking in Contemporary Democracies, Party Politics 13, no. 2 (2007), 235-254, https://doi.org/10.1177/1354068807073875; Petr Kopecký / Peter Mair / Maria Spirova, eds, Party Patronage and Party Government in European Democracies, Oxford 2012.

54 Andreas Bågenholm / Nicholas Charron, Do Politics in Europe Benefit from Politicising Corruption?, West European Politics 37, no. 5 (2014), 903-931, DOI: 10.1080/01402382.2014.909164. 
such (citizens are far from sanctioning MPs who are either under investigation or vocally support strong immunity protection and vote accordingly) provide us with the general contours of a political environment similar to those of other democracies. However, the Romanian case remains explanatory for the limitations entailed by European pressure on the adoption of anticorruption policies. The abandonment of consensus on anticorruption policies precisely at the moment when such policies appear to have reached their maximum efficiency constitutes a backlash effect of a systematic campaign against corruption that did not provide alternative or correlative policies and social reforms.

The literature often associates this form of disenchantment with the new social stratification and inequalities resulting from (neo)liberal initiatives, the lack of political incentives for national leaders to endorse the anticorruption drives (in terms of electoral rewards), the backlash effects of the EU process of integration, etc. ${ }^{55}$ However, in Romania, such narratives about integrity in politics (the general agreement on the principle of the 2000s notwithstanding) constitute a polarizing factor, resulting in trans-partisan denunciations of both corruption and anticorruption. The large number of cases, as well as their different impacts, have generated not only a discourse on good practices in politics but also have generated a critical discourse against anticorruption, leading to the denial of the possibility of reconciling anticorruption with the rule of law or individual rights and freedoms. A passage was made from contesting discrete cases and perhaps institutions to challenging the tenets of anticorruption as such. More and more, Romanian MPs are questioning to what degree is good governance compatible with policies acting as effective straitjackets on political elites, but in doing so, they adopt for the first time in the last thirty years the tools of reflexivity. Questions concerning the role of parliamentary representation, the limits and scope of autonomy, the role and the significance of the 'rule of law' are starting to appear.

\section{CORRESPONDING AUTHOR}

Alexandra lancu University of Bucharest, Faculty of Political Science, Calea Plevnei nr. 59, 010223 Bucharest, Romania. E-mail: alexandra.ionascu@fspub.unibuc.ro

55 Christoph H. Stefes, Understanding Post-Soviet Transitions. Corruption, Collusion and Clientelism, New York, Basingstoke 2006, 65-84; Ivan Krastev, Shifting Obsessions. Three Essays on the Politics of Anticorruption, Budapest, New York 2004, 46, 52; Ivan Krastev / Georgy Ganev, The Missing Incentive. Corruption, Anticorruption, and Reelection, in: János Kornai / Susan Rose-Ackerman, eds, Building a Trustworthy State in Post-Socialist Transition, New York 2004, 151-172; Ivan Krastev, Is Central Europe Backsliding? The Strange Death of Liberal Consensus, Journal of Democracy 18, no. 4 (2007), 56-63, DOI: 10.1353/jod.2007.0072. 